\title{
PENGAMATAN PERTUMBUHAN KAMBING PERANAKAN ETAWAH YANG DIPELIHARA INTENSIF DI KABUPATEN MANOKWARI
}

\section{OBSERVATION OF GROWTH THE PERANAKAN ETAWAH GOATS IN INTENSIVE MAINTENANCE IN MANOKWARI REGENCY}

\author{
Nani Zurahmah \\ Sekolah Tinggi Penyuluhan Pertanian Manokwari
}

\section{ABSTRACT}

Article history

Accepted: May 4, 2018 ;

Approved: June 1, 2018

* Corresponding author:

E-mail:

nazur201162@gmail.com
This study aims to observe the growth of Peranakan Etawah goats (PE goat) that are maintained intensive in Manokwari regency. The research material used was $50 \mathrm{PE}$ goats that were born from 42 parents. The research method used is suvei with case study technique. The sample of pregnant goat used was taken by purposive sampling. The observed variables were birth weight, body weight 90 days and daily weight gain of goats studied. Data on the results of the study were analyzed using the t-test to compare growth of the goats observed by type of birth (single vs twin) and sex (male vs female). The results of statistical analysis showed that birth weight $(3.01 \pm 0.44 \mathrm{~kg})$ and body weight 90 days $(9.09 \pm 1.77$ $\mathrm{kg})$ in single-birth-type $\mathrm{PE}$ goats were higher $(\mathrm{P}<0.05)$ than birth weight $(2.76$ $\pm 0.44 \mathrm{~kg})$ and body weight of 90 days $(8.07 \pm 1.67 \mathrm{~kg})$ in twin goat birth type. However, the single birth weight of single-birthed PE goats $(65.58 \pm 17.53 \mathrm{~g})$ was statistically not different $(\mathrm{P}>0.05)$ with the multiple births $(58.96 \pm 19.23 \mathrm{~g})$. Also known that birth weight $(3.16 \pm 0.47 \mathrm{~kg})$ and body weight 90 days $(9.22 \pm$ $1.77 \mathrm{~kg})$ in male PE goats was higher $(\mathrm{P}<0.05)$ than birth weight $(2.68 \pm$ $0.29 \mathrm{~kg})$ and body weight 90 days $(8.27 \pm 1.71 \mathrm{~kg})$ in the female. While the weight of male goat PE $(64.26 \pm 18.86 \mathrm{~g})$ was statistically not different $(\mathrm{P}>0.05)$ with the female $(62.18 \pm 17.79 \mathrm{~g})$.

Keywords: PE goat, growth, birth type, sex.

\section{PENDAHULUAN}

Kambing Peranakan Etawah (PE) merupakan hasil persilangan antara kambing Etawah dengan kambing Kacang. Batubara dkk. (2016) menginformasikan bahwa ciri-ciri dominan pada rumpun Kambing PE adalah telinganya panjang dan terkulai sampai 18 $30 \mathrm{~cm}$, warna bulu bervariasi dari coklat muda sampai hitam, pada yang jantan bulu bagian atas leher, pundak lebih tebal dan agak panjang, sedang yang betina bulu panjangnya hanya terdapat pada bagian paha, bobot badan jantan dewasa $40 \mathrm{~kg}$ dan betina $35 \mathrm{~kg}$ dan tinggi pundaknya 76-100 cm (SNI 7325.2008). Hingga kini kambing PE telah menyebar luas hampir ke seluruh pelosok tanah air, termasuk di tanah Papua. Kambing PE diintroduksikan ke wilayah kabupaten Manokwari, provinsi
Papua Barat pada tahun 2007 sebanyak 450 ekor (Fatem, 2016).

Kemampuan produksi kambing PE di berbagai lokasi di Indonesia masih sangat beragam. Sutama (2007) melaporkan bahwa berat lahir kambing PE sebesar $3,71 \pm 0,98 \mathrm{~kg}$. Penelitian Kurnianto, dkk. (2007) di Pusat Pembibitan Kambing Sumberrejo Kendal menemukan bahwa kambing PE yang dilahirkan tunggal memiliki berat lahir $(3,47 \pm$ $0,46 \mathrm{~kg}$ ) lebih tinggi dibandingkan yang dilahirkan kembar dua $(3,00 \pm 0,35 \mathrm{~kg})$, dan berat lahir kambing PE jantan $(3,34 \pm 0,48 \mathrm{~kg})$ lebih tinggi dibandingkan yang betina $(3,12 \pm 0,44 \mathrm{~kg})$. Kaunang dkk. (2013) melaporkan bahwa jenis kelamin berpengaruh terhadap berat lahir kambing PE. Hasil penelitiannya menunjukkan bahwa rata-rata berat lahir kambing PE jantan $(3,36 \pm 0,40 \mathrm{~kg})$ lebih tinggi dibandingkan rata-rata berat lahir 
yang betina $(2,49 \pm 0,32)$. Setiadi dan Sitorus (1984) juga melaporkan bahwa berat lahir kambing PE jantan $(2,56 \mathrm{~kg})$ lebih tinggi dibandingkan berat lahir yang betina $(2,46 \mathrm{~kg})$.

Anak kambing akan disapih induknya ketika produksi air susu induk telah menurun atau terhenti. Direktorat Bina Produksi Peternakan (1981) menetapkan umur sapih 90 hari, dengan alasan anak kambing sudah cukup menerima air susu dari induknya dan telah mampu memakan pakan padat. Menurut Sutama (2007) berat sapih dipengaruhi oleh kondisi induk, serta jumlah dan kondisi anak yang dilahirkan. Lu (2002) menambahkan bahwa berat sapih pada kambing bervariasi dan tergantung pada faktor genetik, umur sapih, kesehatan serta manajemen pemeliharaan, terutama aspek pemberian pakan yang sangat berpengaruh terhadap kemampuan induk memproduksi susu selama masa pertumbuhan pra sapih anaknya.

Kambing termasuk ternak yang prolifik, dapat beranak kembar dua, bahkan kembar tiga sepelahiran walaupun persentasenya rendah. Faozi dkk. (2013) melaporkan bahwa tipe kelahiran berpengaruh terhadap berat sapih anak kambing. Anak kambing yang dilahirkan tunggal memiliki berat tubuh lebih tinggi dibandingkan yang dilahirkan kembar. Kompetisi diantara saudara kembar dalam memperoleh air susu induk diduga sebagai penyebab rendahnya berat sapih anak kambing yang dilahirkan kembar. Ngadiyono dkk. (1984) melaporkan bahwa pada pemeliharaan tradisional, persentase induk kambing yang melahirkan anak tunggal, kembar-2 dan kembar-3 berturut-turut sebesar 56,25\%, $31,25 \%$, dan $12,50 \%$. Setiadi dan Sitorus (1984) melaporkan bahwa tipe kelahiran tunggal, kembar-2 dan kembar-3 pada kambing PE berturut-turut sebesar $84,2 \%$, 13,4\%, dan 2,4\%. Sodiq dan Sadewo (2008) menyatakan bahwa liiter size kambing sangat dipengaruhi oleh paritas dan ukuran badan induk. Induk dengan postur tubuh yang besar menghasilkan jumlah anak seperindukan lebih besar. Hasil penelitian Kaunang dkk. (2013) menemukan bahwa litter size kambing PE sebesar 1,5 ekor per kelahiran.

Faozi dkk. (2013) melaporkan bahwa tipe kelahiran berpengaruh terhadap berat tubuh pra sapih kambing PE, dimana kambing PE yang terlahir tunggal memiliki berat tubuh lebih tinggi dibandingkan kambing PE yang terlahir kembar. Hasil penelitian Kurnianto, dkk. (2007) juga menemukan berat sapih kambing PE yang terlahir tunggal $(9,59 \pm 1,39$ $\mathrm{kg}$ ) lebih tinggi dibanding berat sapih kambing PE yang terlahir kembar dua $(8,35 \pm 1,28 \mathrm{~kg})$.

Selain tipe kelahiran, jenis kelamin kambing diketahui berpengaruh terhadap berat sapih. Kaunang dkk. (2013) melaporkan bahwa berat sapih kambing PE jantan sebesar $11,7 \pm 1,83 \mathrm{~kg}$ dan $11,5 \pm 2,18 \mathrm{~kg}$ untuk kambing PE betina. Informasi lain menyebutkan berat sapih kambing PE betina sebesar 8,30 kg dan jantan sebesar 9,50 kg (Triwulaningsih, 1988). Setiadi dan Sitorus (1984) melaporkan bahwa berat sapih pada umur 90 hari pada kambing PE jantan $(18,15 \mathrm{~kg})$ lebih tinggi dibandingkan betina $(14,53 \mathrm{~kg})$. Faktor hormon androgen yang terdapat pada jantan diduga sebagai penyebab perbedaan berat lahir dan berat sapih kambing PE jantan dan betina.

Dengan diketahuinya berat lahir dan berat badan pada umur tertentu dari kambing, maka dapat diketahui pertumbuhan atau pertambahan berat badan hariannya. Edey et al. (1983) menyatakan bahwa pertumbuhan pra sapih dipengaruhi oleh faktor genetik, berat lahir, produksi susu induk, tipe kelahiran, umur induk, jenis kelamin, dan umur sapih. Nilai pertambahan berat badan harian pra sapih dapat diketahui dengan menghitung selisih berat badan saat disapih dan berat lahir dibagi umur saat disapih. Setiadi dan Sitorus (1984) melaporkan pertambahan berat badan harian dari lahir sampai disapih umur 90 hari pada kambing PE jantan sebesar 72,93 g/ekor/hari dan pada yang betina sebesar 61, $21 \mathrm{~g} / \mathrm{ekor} / \mathrm{hari}$.

Dari uraian di atas dapat diketahui bahwa kajian mengenai kemampuan produksi dan reproduksi pada kambing PE telah banyak dilakukan para peneliti Indonesia, terutama kambing PE yang berada di wilayah Indonesia bagian barat. Permasalahannya, kajian serupa belum banyak dilakukan di wilayah Indonesia bagian timur. Kondisi alam Papua yang mendukung tersedianya pakan melimpah sepanjang tahun diduga dapat menyebabkan perbedaan kemampuan produksi maupun reproduksi dari bangsa kambing ini dengan wilayah lain di Indonesia. Berdasarkan 
pemikiran tersebut maka penelitian ini dilakukan dengan tujuan mengamati pertumbuhan anak kambing $\mathrm{PE}$ yang dipelihara secara intensif di wilayah kabupaten Manokwari.

\section{METODE PENELITIAN}

Bahan penelitian yang digunakan adalah 50 anak kambing PE yang dilahirkan dari 42 induk. Teknik pengambilan sampel induk bunting dilakukan secara purposive sampling. Kriteria pemilihan induk bunting kambing PE sebagai sampel adalah induk bunting kambing PE, induk tersebut berumur kurang dari 5 tahun (berdasarkan gigi geligi), dan dipelihara secara intensif di wilayah penelitian. Alat yang digunakan adalah timbangan kapasitas $100 \mathrm{~kg}$ (ketelitian $0,5 \mathrm{~kg}$ ). Metode penelitian yang digunakan adalah survei dengan teknik studi kasus. Sebagai kasus adalah induk kambing PE dan anaknya yang dilahirkan dan dipelihara intensif dalam kondisi lingkungan pemeliharaan di Manokwari.

Pengamatan dilakukan langsung di lapang terhadap anak kambing PE yang dilahirkan, meliputi tipe kelahiran, jenis kelamin, berat lahir dan berat badan umur 90 hari. Penimbangan berat lahir dilakukan tidak lebih dari 24 jam setelah dilahirkan induknya. Berdasarkan data berat lahir $(\mathrm{kg})$ dan berat badan umur 90 hari $(\mathrm{kg})$, dilakukan penghitungan pertambahan berat badan harian masing-masing anak kambing PE yang diamati dengan formula: Pertambahan berat badan harian $(\mathrm{g} / \mathrm{ekor} /$ hari $)=[\{$ (berat badan umur 90 hari - berat lahir)/90 hari\} x $1.000 \mathrm{~g}]$.

Data berat lahir, berat badan umur 90 hari dan pertambahan berat badan harian yang diperoleh dianalisis menggunakan uji-t 2 untuk membandingkan pertumbuhan anak kambing yang diamati berdasarkan tipe kelahiran (tunggal vs kembar) dan jenis kelamin (jantan vs betina). Hipotesis yang diajukan adalah: (1) berat lahir, berat badan umur 90 hari dan pertambahan berat badan harian kambing $\mathrm{PE}$ tipe kelahiran tunggal lebih tinggi dibandingkan kambing $\mathrm{PE}$ tipe kelahiran kembar; (2) berat lahir, berat badan umur 90 hari dan pertambahan berat badan harian kambing PE jantan lebih tinggi dibandingkan kambing PE betina. Analisis data dilakukan dengan bantuan MINITAB Release 13.2 for Windows.

\section{HASIL DAN PEMBAHASAN}

Data berat lahir, berat badan umur 90 hari dan pertambahan berat badan harian yang dikelompokkan berdasarkan tipe kelahiran dan jenis kelamin pada kambing PE yang diteliti, disajikan dalam Tabel 1.

Tabel 1. Data berat lahir, berat badan umur 90 hari dan pertambahan berat badan harian (PBBH) berdasarkan tipe kelahiran dan jenis kelamin pada kambing PE penelitian.

\begin{tabular}{lcccc}
\hline \multirow{3}{*}{ Variabel Pengamatan } & \multicolumn{2}{c}{ Tipe Kelahiran } & \multicolumn{2}{c}{ Jenis Kelamin } \\
\cline { 2 - 5 } & $\begin{array}{c}\text { Tunggal } \\
(\mathrm{n}=34)\end{array}$ & $\begin{array}{c}\text { Kembar-2 } \\
(\mathrm{n}=16)\end{array}$ & $\begin{array}{c}\text { Jantan } \\
(\mathrm{n}=26)\end{array}$ & $\begin{array}{c}\text { Betina } \\
(\mathrm{n}=24)\end{array}$ \\
\hline Berat Lahir (kg) & $3,01 \pm 0,44^{\mathrm{a}}$ & $2,76 \pm 0,46^{\mathrm{b}}$ & $3,16 \pm 0,47^{\mathrm{a}}$ & $2,68 \pm 0,29^{\mathrm{b}}$ \\
Berat Badan 90 Hari (kg) & $9,09 \pm 1,77^{\mathrm{a}}$ & $8,07 \pm 1,67^{\mathrm{b}}$ & $9,22 \pm 1,77^{\mathrm{a}}$ & $8,28 \pm 1,71^{\mathrm{b}}$ \\
PBBH (g/hari/ekor) & $67,58 \pm 17,53^{\mathrm{a}}$ & $59,00 \pm 19,23^{\mathrm{a}}$ & $67,26 \pm 18,86^{\mathrm{a}}$ & $62,18 \pm 17,79^{\mathrm{a}}$ \\
\hline
\end{tabular}

${ }^{*}$ Superskrip yang berbeda dalam baris yang sama tipemenunjukkan terdapat perbedaan signifikan $(\mathrm{P}<0,05)$.

\section{Berat lahir}

Hasil analisis statistik terhadap data penelitian ini diketahui bahwa kambing PE tipe kelahiran tunggal memiliki berat lahir $(3,01 \pm 0,44 \mathrm{~kg})$ lebih tinggi $(\mathrm{P}<0,05)$ dibandingkan tipe kelahiran kembar $(2,76 \pm$ $0,44 \mathrm{~kg})$. Hal ini sesuai dengan temuan Kurnianto, dkk. (2007) bahwa rata-rata berat lahir kambing PE dengan tipe kelahiran tunggal $(3,47 \pm 0,46 \mathrm{~kg})$ lebih tinggi secara signifikan daripada rata-rata berat lahir kambing PE dengan tipe kelahiran kembar dua $(3,00 \pm 0,35 \mathrm{~kg})$. Faktor yang menyebabkan berat lahir lebih kecil pada tipe kelahiran kembar kemungkinan berkaitan dengan kapasitas uterus induk sewaktu bunting yang lebih padat daripada fetus tunggal. Kapasitas yang terlalu padat pada tipe kembar 
menyebabkan kompetisi dalam mendapatkan nutrisi dari induk sehingga menyebabkan berat lahir yang rendah. Selain itu fetus tunggal tentunya mendapat suplai nutrisi yang lebih besar daripada fetus kembar.

Selain tipe kelahiran, hasil penelitian ini juga memperlihatkan bahwa jenis kelamin mempengaruhi berat lahir (Tabel 1). Pada penelitian ini diketahui bahwa rata-rata berat lahir kambing PE jantan $(3,16 \pm 0,47 \mathrm{~kg})$ lebih tinggi secara signifikan dibandingkan kambing PE betina $(2,68 \pm 0,29 \mathrm{~kg})$. Penelitian ini sesuai dengan laporan Kurnianto dkk. (2007) bahwa rata-rata berat lahir kambing $P E$ jantan $(3,34 \pm 0,48 \mathrm{~kg})$ lebih tinggi dibandingkan yang betina $(3,12 \pm 0,44 \mathrm{~kg})$. Demikian pula hasil penelitian Kaunang dkk. (2013) yang melaporkan bahwa rata-rata berat lahir kambing PE jantan $(3,36 \pm 0,40 \mathrm{~kg})$ lebih tinggi dari rata-rata berat lahir kambing $\mathrm{PE}$ betina $(2,49 \pm 0,32 \mathrm{~kg})$.

Rata-rata berat lahir kambing PE jantan yang ditemukan penelitian ini $(3,16 \pm 0,47 \mathrm{~kg})$ masih lebih rendah dibandingkan laporan Kurnianto dkk. (2007), yaitu sebesar $3,34 \pm 0,48 \mathrm{~kg}$, maupun laporan Kaunang dkk. (2013), yaitu sebesar 3,36 $\pm 0,40 \mathrm{~kg}$, namun lebih tinggi dibandingkan laporan Setiadi dan Sitorus (1984), yaitu hanya sebesar $2,56 \mathrm{~kg}$. Untuk rata-rata berat lahir kambing PE betina yang ditemukan pada penelitian ini $(2,68 \pm 0,29$ $\mathrm{kg}$ ) jauh lebih rendah dibandingkan laporan Kurnianto dkk. (2007) yaitu sebesar 3,12 $\pm 0,44$ $\mathrm{kg}$, namun lebih tinggi dibandingkan laporan Kaunang dkk. (2013), yaitu sebesar 2,49 $\pm 0,32$ $\mathrm{kg}$, dan juga laporan Setiadi dan Sitorus (1984), yang menemukan berat lahir kambing PE betina hanya sebesar $2,46 \mathrm{~kg}$. Perbedaan berat lahir kambing jantan dan betina diduga sebagai akibat faktor hormon androgen yang terdapat pada sistem hormonal kambing jantan sehingga menyebabkan berat lahir jantan lebih tinggi dibandingkan betina.

\section{Berat badan umur 90 hari}

Hasil analisis statistik menunjukkan bahwa tipe kelahiran tunggal pada anak kambing PE yang diamati dalam penelitian ini memiliki berat badan umur 90 hari $(9,09 \pm$ $1,77 \mathrm{~kg})$ lebih tinggi $(\mathrm{P}<0,05)$ dibandingkan tipe kelahiran kembar $(8,07 \pm 1,67 \mathrm{~kg})$. Hasil penelitian ini sesuai dengan laporan Faozi dkk.
(2013) bahwa tipe kelahiran berpengaruh nyata $(\mathrm{P}<0,05)$ terhadap berat tubuh pra sapih kambing $\mathrm{PE}$, dimana kambing $\mathrm{PE}$ yang dilahirkan tunggal memiliki berat tubuh lebih tinggi dibandingkan kambing PE yang dilahirkan kembar. Hasil penelitian Kurnianto, dkk. (2007) di Pusat Pembibitan Kambing Sumberrejo Kendal juga melaporkan rata-rata berat sapih umur 90 hari kambing PE tipe kelahiran tunggal adalah $(9,59 \pm 1,39 \mathrm{~kg})$ lebih tinggi secara signifikan dibanding rata-rata berat sapih umur 90 hari kambing PE dengan tipe kelahiran kembar dua $(8,35 \pm 1,28 \mathrm{~kg})$.

Faktor yang menyebabkan adanya perbedaan berat badan pada saat disapih pada kambing PE yang dilahirkan tunggal dan kembar diduga dikarenakan adanya kompetisi yang ketat antara anak kambing yang dilahirkan kembar dalam memperoleh air susu induknya, sementara produksi susu induknya terbatas. Kompetisi ini menyebabkan nutrisi yang diperoleh untuk pertumbuhan anak kambing yang dilahirkan kembar lebih sedikit dibandingkan anak kambing yang dilahirkan tunggal, sehingga berat badan saat disapih pada anak kambing kelahiran tunggal lebih tinggi dibandingkan berat badan saat disapih anak kambing yang dilahirkan kembar. Dugaan ini diperkuat dengan pernyataan $\mathrm{Lu}$ (2002) bahwa berat badan saat disapih pada kambing bervariasi dan tergantung pada faktor genetik, umur saat disapih, kesehatan serta manajemen pemeliharaan, terutama adalah aspek pemberian pakan yang sangat berpengaruh terhadap kemampuan induk dalam memproduksi susu selama masa pertumbuhan kambing sebelum disapih.

Selain tipe kelahiran, faktor jenis kelamin kambing PE juga berpengaruh terhadap berat badan saat disapih. Dalam penelitian ini ditemukan bahwa rata-rata berat sapih umur 90 hari pada kambing $\mathrm{PE}$ jantan $(9,22 \pm 1,77 \mathrm{~kg})$ lebih tinggi $(\mathrm{P}<0,05)$ dibandingkan dengan yang betina $(8,27 \pm 1,71 \mathrm{~kg})$. Hasil penelitian ini sesuai dengan laporan Kurnianto, dkk (2007) bahwa rata-rata berat sapih umur 90 hari pada kambing PE jantan $(9,00 \pm 1,42 \mathrm{~kg})$ lebih tinggi secara signifikan dibandingkan berat sapih umur 90 hari pada kambing PE betina $(8.97 \pm 1.54 \mathrm{~kg})$. Sulastri $(2001)$ juga melaporkan hasil penelitian di UPPT Singosari Kabupaten Malang, bahwa rata-rata 
berat sapih 90 hari kambing PE jantan dan betina masing-masing $19,82 \pm 0,19 \mathrm{~kg}$ dan $18,62 \pm 2,01 \mathrm{~kg}$.

Berat sapih kambing PE jantan maupun betina yang ditemukan pada penelitian ini jauh lebih rendah dibandingkan dengan laporan Setiadi dan Sitorus (1984) bahwa berat sapih umur 90 hari pada kambing PE jantan sebesar $18,15 \mathrm{~kg}$, dan yang betina sebesar $14,53 \mathrm{~kg}$. Kaunang dkk. (2013) juga melaporkan bahwa berat sapih kambing PE yang berasal dari hasil perkawinan alami adalah sebesar $11,7 \pm 1,83 \mathrm{~kg}$ $(\mathrm{n}=34)$ untuk yang jantan dan $11,5 \pm 2,18 \mathrm{~kg}$ $(n=34)$ untuk cempe betina. Namun, berat sapih yang ditemukan dalam penelitian ini hampir sama dengan yang dilaporkan Triwulaningsih (1988) yaitu sebesar $8,30 \mathrm{~kg}$ untuk kambing PE betina dan yang jantan sebesar 9,50 kg. Perbedaan berat sapih antara kambing jantan dan betina ini diduga disebabkan adanya hormon androgen yang terkandung dalam tubuh ternak jantan, dan juga nafsu makan ternak jantan lebih tinggi dibandingkan betina. Hormon androgen berfungsi meningkatkan retensi nitrogen, dan retensi nitrogen yang tinggi akan meningkatkan pertumbuhan. Oleh karena itu berat sapih kambing PE jantan akan lebih tinggi dibandingkan kambing PE betina.

\section{Pertambahan berat badan harian (PBBH)}

Pada Tabel 1 terlihat bahwa rata-rata PBBH hingga umur 90 hari pada kambing PE yang dilahirkan tunggal $(67,58 \pm 17,53$ g/ekor/hari) lebih tinggi dibandingkan kambing PE yang dilahirkan kembar $(58,96 \pm 19,23$ gram $)$. Demikian pula rata-rata PBBH hingga umur 90 hari pada kambing PE jantan $(67,26 \pm 18,8$ g/ekor/hari) terlihat lebih tinggi dibandingkan dengan yang betina $(62,18 \pm 17,79$ g/ekor/hari). Nilai rata-rata PBBH hingga umur 90 hari pada kambing PE jantan yang ditemukan dalam penelitian ini lebih rendah dibandingkan laporan Setiadi dan Sitorus (1984), yaitu sebesar 72,93 g/ekor/hari, namun rata-rata $\mathrm{PBBH}$ hingga umur 90 hari pada kambing PE betina dalam penelitian ini sedikit lebih tinggi dari laporan Setiadi dan Sitorus (1984), yaitu sebesar 61,21 g/ekor/hari.

Hasil analisis statistik (Tabel 1) terhadap data PBBH sejak lahir hingga umur 90 hari yang ditemukan dalam penelitian ini menunjukkan bahwa $\mathrm{PBBH}$ tersebut tidak dipengaruhi $(\mathrm{P}>0,05)$ oleh perbedaan tipe kelahiran (tunggal vs kembar) maupun jenis kelamin (jantan vs betina). Hasil penelitian ini tidak sesuai dengan pernyataan Edey et al. (1983) yang menyatakan bahwa pertumbuhan sebelum disapih dipengaruhi oleh faktor genetik, tipe kelahiran dan jenis kelamin anak kambing, disamping faktor lain seperti berat lahir, produksi susu induk, umur induk dan umur sapih. Diduga penyebab ketidaksesuaian ini karena faktor lingkungan penelitian yang berbeda dan juga jumlah sampel penelitian ini kurang banyak.

\section{KESIMPULAN}

Tipe kelahiran tunggal pada kambing PE yang dipelihara intensif di Manokwari menampilkan berat lahir dan berat badan umur 90 hari yang lebih tinggi dibandingkan tipe kelahiran kembar. Penampilan berat lahir dan berat badan umur 90 hari yang tinggi juga diperlihatkan pada kambing PE jantan dibandingkan yang betina. Namun, perbedaan tipe kelahiran maupun jenis kelamin tidak memperlihatkan perbedaan pertambahan berat badan sejak lahir hingga umur 90 hari pada kambing PE yang dipelihara intensif di Manokwari.

\section{UCAPAN TERIMA KASIH}

Ucapan terima kasih penulis sampaikan kepada Ketua STPP Manokwari yang telah memberi dana penelitian dosen tahun 2016 sehingga penelitian ini dapat terlaksana. Ucapan terima kasih juga penulis sampaikan kepada para penyuluh pertanian yang membantu dalam pelaksanaan penelitian ini.

\section{DAFTAR PUSTAKA}

Batubara, A., S. Nasution, Subandriyo, I. Inounu, B. Tiesnamurti, A. Anggraeni. 2016. Kambing Peranakan Etawah (PE). Indonesian Agency for Agricultural Research and Development (IAARD) Press. Badan Penelitian dan Pengembangan Pertanian, Pasarminggu, Jakarta . hlm. 19. 
Direktorat Bina Produksi Peternakan. (1981). Pola Operasional Pembinaan Sumber Bibit Kambing. Direktorat Bina Produksi Peternakan, Ditjen Peternakan, Departemen Pertanian, Jakarta. hlm. 11.

Edey, T.N., A.C. Bray, R.S. Copland, and T. O'Shea. (1983). A Course Manual In Tropical Sheep and Goat Production. AUIDP, Australian Vice-Chancellors Committee, Canbera.

Faozi, A.N., A. Priyono, P. Yuwono. (2013). Ukuran Vital Tubuh Cempe Pra Sapih dan Hubunganya dengan Bobot Tubuh Berdasarkan Tipe Kelahiran pada Kambing Peranakan Etawah. Jurnal Ilmiah Peternakan. 1(1): 184-194.

Fatem, H. (2016). Komunikasi Pribadi dengan Kepala Dinas Peternakan dan Kesehatan Hewan, Provinsi Papua Barat.

Kurnianto, E., S. Johari dan H. Kurniawan. (2007). Komponen Ragam Bobot Badan Kambing Peranakan Etawa di Balai Pembibitan Ternak Kambing Sumberrejo Kabupaten Kendal. $J$. Indon.Trop.Anim.Agric. 32 [4]: 236 - 244.

Kaunang, D., Suyadi, S. Wahjuningsih. (2013). Analisis Litter Size, Bobot Lahir dan Bobot Sapih Hasil Perkawinan Kawin Alami dan Inseminasi Buatan Kambing Boer dan Peranakan Etawah (PE). Jurnal Ilmu-Ilmu Peternakan. 23(3):41-46. doi: https://doi.org/

Lu, C.D. (2002). Boer Goat Production: Progress and Perspective. Vice Chamcellor of Academic Affairs, Univesity of Hawai'I Hilo, Hawai. https://hilo.hawaii.edu/uhh/vcaa/ documents/BoerGoatProductionProgressa ndPerspective2002.pdf. Tanggal 25 Agustus 2014.
Ngadiyono, N., P. Basuki, dan G. Murdjito. (1984). Beberapa Data Performans Ternak Kambing yang Dipelihara Secara Tradisional di Pedesaan Sejak Lahir sampai dengan Umur Sapih. Di dalam: Proceeding Pertemuan Ilmiah Penelitian Ruminansia Kecil. Bogor 22-23 Nopember 1983. hlm. 122 -125.

Setiadi, B. dan P. Sitorus. (1984). Penampilan Reproduksi dan Produksi Kambing Peranakan Etawah. DI dalam: Proceeding Pertemuan Ilmiah Penelitian Ruminansia Kecil. Bogor 22-23 Nopember 1983. hlm. 118-121.

Sodiq, A. dan Sadewo. (2008). Reproductive Performance anda Preweaning Mortality of Paeranakan Etawah Goat under Production System of Goat Farming Group in Gumelar Banyumas. Animal Production. 10(2):67-72.

Sulastri. (2001). Estimasi nilai bobot sapih dan MPPA (Most Probable Producing Ability) induk kambing PE di Unit Pelaksana Teknis Ternak Singosari Malang Jawa Timur. Sains Teks Jurnal Ilmiah. 3:282287.

Sutama, I.K. (2007). Pengembangan kambing perah: suatu alternatif peningkatan produksi susu dan kualitas konsumsi gizi keluarga di pedesaan. Seminar Nasional Hari Pangan Sedunia XXVII, Balai Penelitian Ternak Bogor.

Triwulaningsih, E. (1988). Faktor-faktor yang Mempengaruhi Bobot Sapih Kambing Peranakan Etawah (PE). Prosiding Seminar Program Penyediaan Pakan dalam Upaya Mendukung Industri Peternakan Menyongsong Pelita V. Fakultas Peternakan, Univesitas Diponegoro, Semarang. hlm. 209-213. 
Tabel 1. Data berat lahir, berat badan umur 90 hari dan pertambahan berat badan harian $(\mathrm{PBBH})$ berdasarkan tipe kelahiran dan jenis kelamin pada kambing PE penelitian.

\begin{tabular}{lcccc}
\hline & \multicolumn{2}{c}{ Tipe Kelahiran } & \multicolumn{2}{c}{ Jenis Kelamin } \\
\cline { 2 - 5 } Variabel Pengamatan & $\begin{array}{c}\text { Tunggal } \\
(\mathrm{n}=34)\end{array}$ & $\begin{array}{c}\text { Kembar-2 } \\
(\mathrm{n}=16)\end{array}$ & $\begin{array}{c}\text { Jantan } \\
(\mathrm{n}=26)\end{array}$ & $\begin{array}{c}\text { Betina } \\
(\mathrm{n}=24)\end{array}$ \\
\hline Berat Lahir (kg) & $3,01 \pm 0,44^{\mathrm{a}}$ & $2,76 \pm 0,46^{\mathrm{b}}$ & $3,16 \pm 0,47^{\mathrm{a}}$ & $2,68 \pm 0,29^{\mathrm{b}}$ \\
Berat Badan 90 Hari (kg) & $9,09 \pm 1,77^{\mathrm{a}}$ & $8,07 \pm 1,67^{\mathrm{b}}$ & $9,22 \pm 1,77^{\mathrm{a}}$ & $8,28 \pm 1,71^{\mathrm{b}}$ \\
PBBH (g/hari/ekor) & $67,58 \pm 17,53^{\mathrm{a}}$ & $59,00 \pm 19,23^{\mathrm{a}}$ & $67,26 \pm 18,86^{\mathrm{a}}$ & $62,18 \pm 17,79^{\mathrm{a}}$ \\
\hline
\end{tabular}

${ }^{*}$ Superskrip yang berbeda dalam baris yang sama tipemenunjukkan terdapat perbedaan signifikan $(\mathrm{P}<0,05)$. 